\title{
CORAK PEMIKIRAN IMAM ABU HANIFAH DAN RELEVANSINYA DENGAN HUKUM NIKAH TANPA WALI
}

\author{
Heri Mahfudhi \\ Institut Agama Islam Negeri Salatiga \\ Email: mahfudhi@iainsalatiga.ac.id
}

\begin{abstract}
Ro'yu or reason in the ijtihad of Islamic law is a necessity that cannot be avoided. Abu Hanifah or the Hanafi school which is among the most senior schools of thought in the ijtihad ahlussunnah wal jama'ah thought is known as a group that often uses reason or ro'yu in ijtihad. Among the ijtihad produced by the Hanafi school in the field of Islamic family law is that it is permissible for woman to marry without guardian. This phenomenon is inseparable from the socio-cultural influence experienced by Abu Hanifah and his followers. So that this also has a significant influence on the discourse of family law thought. The purpose of this study is to find information related to the style of thinking of Abu Hanifah's ijtihad and Hanafi schools related to the field of Islamic family law. This study uses library research that focuses on the object of study in existing books and literature. While the method used in this study is a descriptive-analytical method by providing an overview and analyzing the patterns of thought of the Hanafi school of thought on the impact on the permissibility of marriage without a guardian. Thus also affecting the results of existing ijtihad. At the same time, it also strengthens the paradigm that the results of ijtihad Islamic law cannot be binding as long as it is still in the realm of ikhtilaf of fiqh experts.
\end{abstract}

Keywords: Marriage, Abu Hanifah's thoughts

\begin{abstract}
Abstrak
Ro'yu atau nalar dalam proses ijtihad hukum Islam adalah sebuah keniscayaan yang tidak bisa dihindari. Abu hanifah atau madzhab Hanafi yang termasuk mazhab paling senior dalam pemikiran ijtihad ahlussunnah wal jama'ah adalah dikenal sebagai golongan yang sering menggunakan nalar atau ro'yu dalam berijtihad. Diantara ijtihad yang dihasilnya oleh madzhab Hanafi dalam bidang hukum keluarga Islam adalah bolehnya menikah wali bagi si wanita. Fenomena ini ternyata tidak terlepas dari pengaruh sosio kultur yang dialami oleh Abu hanifah dan pengikutnya. Sehingga hal ini juga memiliki pengaruh sigifikan pada diskursus pemikiran hukum keluarga, Tujuan penelitian ini hendak mencari informasi terkait corak pemikiran ijtihad Abu hanifah dan madzhab Hanafi terkait bidang hukum keluarga Islam. Penelitian ini menggunakan penelitian kepustakaan yang memfokuskan pada objek kajian pada buku-buku dan literature yang ada. Sedangkan metode yang digunakan dalam penelitian ini adalah metode deskriptif-analisis dengan memberikan gambaran dan menganalisa corak pemikiran madzhab Hanafi dampaknya terhadap bolehnya pernikahan tanpa wali Hasil dari penelitian ini menunjukkan bahwa corak pemikiran suatu madzhab sedikit atau banyak sangat dipengaruhi oleh sosi kultur tumbuh dan berkembangnya madzhab tersebut, sehingga juga mempengaruhi hasil ijtihad yang ada. Sekaligus juga menguatkan paradigma bahwasanya hasil ijtihad hukum Islam tidak bisa mengikat selama masih dalam ranah ikhtilaf para ahli fiqh.
\end{abstract}

Kata kunci: Nikah tanpa wali, emikiran abu hanifah

\section{Pendahuluan}

Abu hanifah adalah seorang ulama besar ahli fiqih yang cukup banyak di ikuti oleh kaum muslimin, khususnya di wilayah Iraq, dan sekaligus merupakan salah satu dari empat imam madzhab yang di akui dan layak diikuti secara 
konsensus oleh ulama kaum muslimin. Bahkan saat ini madzhabnya adalah yang paling banyak tersebar di penjuru negara-negara Islam (Al-Baklabakki, 1992, p. 42). Abu Hanifah sendiri dikenal sebagai mujtahid yang sering menggunakan logika didalam menyimpulkan hukum-hukum. Pernah belajar juga ke beberapa sahabat dan tabi'in yang masih hidup, misalnya Anas bin Malik, bahkan pernah juga ikut mendengar kajiannya Atho' bin Abi Robbah, Abu Ishaq assabi'i, Hammad bin Abi Sulaiman, Qois bin Muslim, Hisyam bin Urwah, dan sebagainya (Bakr, n.d., pp. 323-324).

Abu Hanifah dan madzhabnya memiliki corak fikir yang khas dalam menyimpulkan hukum. Kondisi sosial politik serta wilayah yang dialami Abu Hanifah cukup mewarnai cara pandang beliau didalam menyusun sebuah metodologi meyimpulkan hukum. Termasuk juga profesi atau perkejaan Abu Hanifah sebagai pedagang juga sangat mempengaruhi beliau dalam memahami hukum-hukum syari'ah, khususnya yang berkenaan dengan Muamalah.

Dalam paper yang sederhana dan singkat ini akan sedikit mengupas tentang Imam Abu Hanifah, latar belakang kehidupannya, serta kondisi sosial politik dan wilayah tempat tumbuhnya, juga pendidikan yang ia tempuh. Dan kemudia juga membahas metodologi pengambilan hukum yang dipegang oleh madzhab Abu Hanifah, serta sedikit membahas permasalahan dalam bidang hukum keluarga yang mengacu pada pendapat Madzhab Hanafi dengan menyantumkan metodologi penyimpulan hukumnya. Semoga bermanfaat.

\section{Biografi Imam Abu Hanifah}

Nama aslinya adalah Nu'man bin Tsabit bin Marzuban al-Taimi. Ada juga yang menyebut ayahnya adalah Tsabit bin Zutha, termasuk keturunan Persia, tergolong kedalam keluarga yang mulia . Berasal dari daerah Kabil, yang sekarang adalah ibu kota negara Afghanistan. Kakeknya yang bernama Marzuban masuk Islam ketika masa pemerintahan Amirul Mukminin Umar bin Khottob, yang kemudian pindah hijrah ke Kufah dan bertempat tinggal disana (Ghawji, 1993, p. 47). Keulamaan Abu Hanifah tidak terlepas dari doa yang diucapkan oleh Ali bin Abi Thalib. Sebagaimana hal ini diceritakan oleh Ismail bin Hammad bin Abi Hanifah, ketika kakeknya Abu Hanifah Tsabit bin Marzuban sowan (bertemu) dengan Kholifah Ali bin Abi Thalin yang kemudian didoakan agar ia dan keturunannya senantisa diberi berkah. Dan ternyata doa tersebut dikabulkan oleh Alloh dengan lahirnya seorang Abu Hanifah yang sangat mumpuni dan diakui keilmuaanya (Bakr, n.d., p. 326). Menurut sumber yang kuat, Imam Abu Hanifah dilahirkan di Kufah pada sekitar tahun $80 \mathrm{H}$ atau $699 \mathrm{M}$, tepatnya adalah pada masa pemerintahan Kholifah Abdul Malik bin Marwan (Ghawji, 1993, p. 47). Pada masa pemerintahan Abu Jakfar al-Manshur, Abu Hanifah dipindah-tempatkan ke Baghdad dan bermukim di sana sampai meninggal pada sekitar tahun $150 \mathrm{H}$ atau $767 \mathrm{M}$. Dimakamkan di sisi timur dari Baghdad, tepatnya di pemakaman al-Khaizuran (Bakr, n.d., p. 324). 


\section{Perkembangan dan Pengembaraan Intektual Abu Hanifah}

Imam Abu Hanifah tumbuh besar di Kufah dalam sebuah keluarga Islam yang mulia, terhormat, lagi kaya. Orang tuanya berprofesi sebagai seorang pedagang kain atau baju sutra, sekaligus juga memiliki toko kain di kota Kufah. Profesi bapaknya sebagai pedagang ini kemudian diwarisi dan dilanjutkan oleh Imam Abu Hanifah (Bakr, n.d., p. 324; Ghawji, 1993, p. 49).

Kufah pada saat itu adalah merupakan salah satu kota yang besar di negara Iraq. Sekaligus menjadi sentral pusatnya ilmu dan hadits, cukup banyak para ulama yang berada disana. Imam Bukhori sendiri mengakui bahwa beliau sering keluar masuk Kufah untuk mencari hadits, sampai tidak bisa menghitung berapa kali berkunjung ke kota Kufah. Kondisi ini cukup menjadi faktor yang melatar belakangi perkembangan intelektual Abu Hanifah, yakni dengan banyaknya para ulama yang mudah ia temui di tanah lahirnya sendiri (Ghawji, 1993, p. 57).

Semenjak kecil Abu Hanifah sudah mulai menghafalkan al-Qur'an, namun belum mulai mendengarkan kajian-kajian keilmuan, namun lebih sering menemani orang tuanya di tokonya. Barulah beliau mulai belajar ilmu ketika ia secara tidak disangka bertemu dengan Imam al-Sya'bi, dan pertemuan tersebut sekaligus menjadi awal babak baru dalam kehidupan Abu Hanifah yang sangat berpengaruh baginya (Ghawji, 1993, p. 49).

Pada saat usia 16 tahun, Abu Hanifah diajak orang tuanya untuk menunaikan ibadah haji, sekaligus mengunjungi masjid nabawi berserta maqam Nabi. Kemudian setelah itu Abu Hanifah mulai fokus memperlajari ilmu-ilmu keislaman. Dan ilmu yang awal-awal beliau pelajari adalah ushuluddin serta metodologi berdebat dengan orang-orang sesat yang terkontaminasi dengan ateisme. Abu Hanifah pernah juga debat menghadapi Jahm bin Shofwan sampai membungkamnya. Abu Hanifah juga mendebat kelompok muktazilah, khowarij, dan syi'ah (Ghawji, 1993, pp. 50-51).

Meskipun telah lama Abu Hanifah sering terlibat berdebat dalam masalah-masalah ushuluddin, namun beliau melarang pada murid-murid dan orang-orang terdekatnya dari banyak berdebat. Suatu saat beliau pernah melihat putranya bernama Hammad_yang ketika itu sudah menjadi seorang hakim_berdebat dalam masalah ilmu kalam, lalu Abu Hanifah pun melarang putranya tersebut. Putranya lalu bertanya : "kenapa engkau melarang kami berdebat, sedangkan kau sendiri sering melakukan perdebatan?", Abu Hanifah lalu menjawab : "kami berdebat dalam kondisi atau keadaan seakan-akan diatas kepala kami ada burung (penggambaran untuk sesuatu yang sangat takut), sebab kami khawatir lawan bicara kami keliru atau salah. Namun kalian biasanya berdebat untuk mencari kemenangan sendiri dengan mengharapkan agar lawan debatnya kalah. Padahal siapa saja yang menginginkan kesalahan atau kekeliruan bagi saudaranya sendiri maka ia berarti menginginkan temannya tersebut menjadi kafir. Dan siapa saja yang menginginkan saudaranya kafir maka ia sendiri yang kafir (Ghawji, 1993, pp. 50-51). 
Dalam perjalanan keilmuannya, Abu Hanifah belajar bidang fiqh kepada Syaikh Hammad bin Sulaiman. Dengan kejeniusan dan kecerdasannya, Abu Hanifah terlihat paling menonojol dan unggul diatas teman-temannya, sehingga ia seringkali ditempat-dudukkan di bagian depan dekat dengan tempat duduk syaikhnya. Sikap khidmat dan adab yang dilakukan oleh Abu Hanifah kepada gurunya cukup sangat luar biasa. Jika ingin ketemu gurunya Hammad bin Sulaiman, ia menunggu di depan pintu rumah sang guru sampai gurunya keluar rumah sendiri, dengan tanpa mengetuk pintu rumah sang guru. Ketika duduk, ia pun enggan untuk menjulurkan kakinya ke arah gurunya tersebut. Tiap selesai melakukan sholat, ia senantiasa mendoakan guru dan orang tuanya (Ghawji, 1993, p. 55). Abu Hanifah berguru kepada Hammad bin Sulaiman selama sekitar sepuluh tahun, ada juga yang menyebut lima belas tahun (Addzahabi Muhammad bin Ahmad bin Utsman, n.d., p. 11). Ia menemani gurunya tersebut sampai meninggal dunia, yang kemudian Abu Hanifah mulai mengadakan kajian keilmuan sendiri (Addzahabi Muhammad bin Ahmad bin Utsman, n.d., p. $61)$.

Imam Abu Hanifah berguru menuntut ilmu kepada sekitar empat ribu syaikh, tujuh dari kalangan sahabat, sembilan puluh tiga dari kalangan tabi'in, dan sisanya adalah tabi'ut tabi'in. Dan ini tidaklah mengherankan, sebab Abu Hanifah hidup dalam umur 70 tahun, dan naik haji sebanyak 55 kali. Sedangkan pada musim haji pasti akan berkumpul para ulama-ulama dari segala penjuru dunia, dan hal ini tentu menjadi momen yang sangat tepat bagi Abu Hanifah untuk melakukan diskusi dan kajian keilmuan (Addzahabi Muhammad bin Ahmad bin Utsman, n.d., p. 57).

Abu Hanifah suatu saat juga pernah ditawari oleh Ibnu Hubairoh untuk menjadi Hakim di wilayah Kufah, namun tawaran ini ditolak oleh Abu Hanifah, yang justeru membuat ia dihukum oleh Ibnu Hubairoh dengan dicambuk pakai cemeti sebanyak seratus sepuluh cambukan, yang setiap harinya 10 kali cambukan. Hukuman inipun tidak membuat Abu Hanifah merubah sikapnya, sehingga ia tetap bersikukuh menolak menjadi Qodli atau Hakim wilayah Kufah. Ibnu Hubairoh sendiri adalah pegawai Malik bin Marwan, Kholifah Dinasti Bani Umayyah ketika itu (Bakr, n.d., p. 326).

\section{Kondisi Sosial Politik pada masa Abu Hanifah}

Abu Hanifah lahir pada tahun $80 \mathrm{H}$, yang pada waktu itu Dinasti Umawiyah dipegang oleh Abdul Malik bin Marwan, sehingga benar-benar mengetahui dan mengalami kondisi dipimpin oleh Bani Umayyah sampai masamasa jatuhnya Dinasti tersebut. Kemudian meninggal pada tahun $150 \mathrm{H}$, sehingga pernah juga mencicipi kepemimpinan Dinasti Abbasiyah yang cukup kuat dan ganas pada awal kemunculannya. Tapi Abu Hanifah lebih banyak merasakan kepemimpinan Bani Umayyah dari pada Bani Abbasiyah, sebab beliau lahir dan tumbuh berkembang serta dewasa pada masa Umawiyyah, yakni selama 52 tahun, sehingga masa inilah yang lebih berpengaruh secara dominan terhadap Abu Hanifah. Menemui masa Abbasiyah hanya sekitar 18 
tahun, dimana hal ini sangat kurang mempengaruhi sosok Abu Hanifah (Zuhroh, 1948, p. 89).

Pada masa Umawiyyah sukup kuat sekali fanatisme golongan terhadap keturunan arab dan terjadi rasa sentimen yang tinggi terhadap yang bukan arab (a'jam), meskipun pada hakikatnya hal ini sangat bertolak belakang dengan konsep Islam yang menyamaratakan semua manusia dihadapan Allah. Cukup banyak peninggalan budaya arab sebelum Islam yang dibangun dan dihidupkan kembali pada masa ini. Hal ini berimplikasi pada kebencian Non-Arab terhadap pemerintahan Umawiyah, sehingga tidak jarang terjadi protes dan ketidakpatuhan terhadap keputusan yang dikeluarkan oleh Dinasti saat itu. Maka banyak gejolak sosial yang dialami oleh pemerintahan Bani Umayyah, dan hal ini dimanfaatkan oleh orang-orang Bani Abbasiyah untuk membuat kekuatan sembunyi demi menjatuhkan Dinasti Umawiyah (Zuhroh, 1948, p. 92). Secara kasat mata Abu Hanifah melihat fenomena realita cukup keras serta kepahitan dan kedzaliman yang dilakukan oleh Bani Ummayah, yang hal ini cukup mempengaruhi sosok Abu Hanifah.

\section{Pondasi Madzhab Abu Hanifah dan Corak Fiqihnya}

Berkenaan dengan dasar dan landasan yang menjadi pondasi bangunan madzhabnya, Abu Hanifah mengatakan : "saya selalu berpegangan pada kitab Allah, jika tidak ada di kitab Allah maka saya berpegang pada sunnah Rasulullah, jika tidak di kitab Allah maupun sunnah Rasulullah maka aku mengambil pendapat sahabat, jika tidak ada maka aku menggunakan ijtihad sendiri".(Ghawji, 1993, p. 130) Sahl bin Muzahim berkata : "pendapat Abu Hanifah senantiasa berdasarkan sumber yang terpercaya dan menjauhi yang buruk. Disamping juga memperhatikan kondisi sosial masyarakat yang ada" (Ghawji, 1993, pp. 130-131).

Pada intinya, sumber ijtihad yang dipegang oleh Abu Hanifah adalah :

1. Al Quran

Bagi Abu Hanifah Al Quran adalah sumber pertama dan utama dalam menyimpulkan hukum, karena bersifat pasti dan valid yang sumbernya dari wahyu Allah (Ghawji, 1993, p. 133).

2. Sunnah

Abu Hanifah tidak menyamaratakan semua jenis sunnah, namun beliau lebih mengutamakan sunah qauliyah (yang bersifat ucapan) dari pada sunnah fi'liyyah (yang bersifat perbuatan). Sebab adanya kemungkinan perbuatan tersebut adalah khusus untuk Nabi. Abu Hanifah lebih mendahulukan sunnah mutawatiroh dari pada sunnah ahad ketika terjadi kontradiksi serta ketika tidak bisa dilakukan kombinasi. Bahkan Abu Hanifah tidak mau mengambil hadits ahad ketika bertentangan dengan kaidah syara' yang bersumber pada Quran dan Sunnah (Ghawji, 1993, pp. 133-134).

3. Ijmak

Selama ada sebuah ijmak dari kalangan sahabat maka Abu Hanifah mengambil ijmak tersebut dan berpaling dari ijmak pendapat lain. 
Dan bagi Abu Hanifah, ijmak adalah hujjah (landasan dalil) yang boleh dilaksanakan (Ghawji, 1993, p. 135).

4. Qiyas

Selama tidak ada dalil hadits baik yang bernilai mursal ataupun dloif, maka Abu Hanifah mengambil langkah Qiyas. Jika ada hadits meskipun nilainya dloif, Abu Hanifah enggan menggunakan Qiyas (Ghawji, 1993, pp. 135-137).

5. Istihsan

Yakni memilih yang dianggap paling baik dan layak untuk di ikuti atau diambil. Bagi Abu Hanifah, istihsan bukanlah menuruti kemauan nafsu, akan tetapi ia adalah memilih salah satu yang paling kuat dari dua dalil dalam sebuah masalah tertentu (Ghawji, 1993, pp. 139-140).

6. Urf atau Adat Kebiasaan

Yakni sesuatu yang diterima oleh jiwa dan naluri manusia yang lurus, selama tidak bertentangan dengan Qur'an dan Sunnah. Jika bertentangan, maka Urf ata Adat tersebut tidak layak dan tidak boleh diambil (Ghawji, 1993, p. 141).

\section{Nikah Tanpa Wali Menurut Abu Hanifah}

Dalam membahas masalah "wali" dalam pernikahan, maka mayoritas fuqoha berpendapat bahwa adanya wali dalam pernikahan adalah salah satu syarat akad dalam nikah (Tulab, 2017), kecuali menurut Madzhab Hanafi.(Wahbah Az-Zuhaili, 2009, Chapter 7 p.705) Imam Abu Hanifah, Zufar, Asy Sya'bi dan Az-Zuhri berpendapat bahwa apabila seorang perempuan melakukan akad nikah tanpa wali, sedang calon suaminya sebanding (kufu'), maka pernikahannya boleh (Hasan, 2000, p. VII).

Menurut Madzhab Hanafi, selama wanita itu merdeka, baligh, berakal, sekufu dengan calon pasangannya, dan memiliki kemampuan penuh untuk bertindak dengan sendirinya, maka ia boleh melakukan akad dengan sendirinya tanpa adanya wali (Hasan, 2000, p. 197).

Menurut Madzhab Hanafi, dalil-dalil yang dipakai sebagai legitimasi adanya wali sebagai syarat nikah adalah lemah dan tidak kuat dipakai sebagai hujjah. Jikapun ada ayat yang dipakai dalam mensyaratkan adanya wali, maka pemakaian ayat tersebut kebanyakan tidak pada konteksnya (Ibn Rusyd, 1995, Chapter 2 p. 8-9).

Abu hanifah dan Abu yusuf mengatakan bahwa wanita yang baligh dan berakal boleh menikahkan dirinya sendiri dan anak perempuannya yang masih belum dewasa (kecil) dan dapat juga sebagai wakil dari orang lain.

Diantara beberapa argumentasi yang dijadikan pegangan oleh pengikut madzhab hanafi adalah firman Allah dalam QS. Al-Baqarah: 230: 


$$
\text { فإن طلقها فلا تحل له من بعد حتى تنكح زوجا غيره }
$$

Artinya : "lalu apabila sang suami mentalaknya (setelah Talak kedua), maka perempuan tersebut tidak lagi halal baginya setelah ia menikah lagi dengan suami selain suaminya yang pertama."

Ayat ini jelas mengatakan bahwa wewenang itu berada pada diri wanita itu. Para wali tidak dipersalahkan (berdosa) bila si wanita itu bertindak atas namanya sendiri. Dalam ayat di atas, akad tersebut dinisbahkan ke si Wanita sendiri.Hal ini secara implisit menunjukkan bahwa perempuan memiliki hak melakukan pernikahan secara langsung dengan tanpa adanya wali (Fakhrudin Al-Rozi, n.d., Chapter 6 p. 449). Disamping itu mereka berpegang pada hadis Rasulullah: "Janda itu lebih berhak atas dirinya daripada walinya, sedangkan gadis itu diminta izinnya dan diamnya menunjukkan izinnya". (HR. jamaah kecuali Bukhari).

Abu Hanifah berpendapat bahwasanya hukumadanya wali dalam sebuah pernikahan adalah sunnah, sebagaimana yang tercantum dalam firman Allah Surat Al Baqarah ayat 234, dikatakan bahwa sebuah akad nikah yang dilaksakan secara sendiri oleh wanita,termasuk juga segala sesuatu yang dilaksanakannya tanpa menyandarkan dirinya kepada adanya wali atau izin wali adalah sah dan tidak melanggar ketentuan syariat. Berpedoman pada ayat tersebut juga, madzhab Hanafi memberikan hak sepenuhnya kepada si perempuan terkait urusan dirinya dengan meniadakan keikutsertaanpihak lain yang dalam hal ini adalah wali.Dalam konteks ini adalah campur tangan wali dalam urusan pernikahan yang dilakukan si perempuan.Pemikiran logis yang sangat rasional inilah yang melatar belakangi pengikut madzhab Hanafidalam membuat kesimpulan hukum bahwa tidak wajib adanya wali nikah bagi wanita yang ingin menikah (Ramulyo, 1996, pp. 218-220).

Dalam hal ini Madzhab Hanafi memakai sebuah logika nalar bahwasanya seandainya memang wali adalah syarat sah nikah, maka pasti dalam syariat akan ada keterangan yang jelas serta pasti tentang jenis wali, macam-macam wali, dan tingkatan-tingkatan wali, namun tidak ada keterangan tentang hal itu. Padahal keterangan mengenai ketentuan yang berkaitan dengan wali ini sangatlah penting (Ramulyo, 1996, p. 11).

Madzhab Hanafi sendiri memahami hadits "lâ nikâha illâ bi waly" bahwasanya lafadz "Lâ" disitu adalah berfungsi "linafyi al kamal" (untuk meniadakan kesempurnaan), bukan "linafyi al shihhah" (meniadakan ke-absahan). Sehingga adanya waly bukanlah syarat sah akad nikah, namun lebih sebagai syarat pelengkap atau penyempurna dalam nikah (Ramulyo, 1996, p. 8).

Pendapat Abu Hanifah ini juga melihat kondisi sosial kehidupan saat itu, dimana masyarakat masih kuat memegang nilai-nilai tanggung jawab, terlebih pada masyarakat Iraq yang cenderung berfikiran logis. Namun pendapat ini terasa kurang sesuai dengan kondisi sosial negara lain, seperti contohnya Indonesia. Sebab ketidak beradaan wali akan memudahkan terjadinya kawin lari yang berimplikasi pada ketidak teraturan tata nilai kehidupan dalam masyarakat. 
Secara sosio kultur, Imam Abu Hanifah sendiri hidup di Kota Kufah, kota kosmopolitan yang pada saat itu cukupsering terjadi pemalsuan hadis yang sangat massif sehingga membuat sulit untuk melacak keshahihan sebuah hadits. Terlebih, perempuan Kufah pada masa itu sudah terbiasa melakukan nikah pada usia sekitar 18-22 tahun, sebuah hitungan umur yang lebih dewasa dari pada standard usia nikah di Baghdad. Pada umur demikian, para wanita tentu sudah bisa mandiri dalam mengambil keputusan sehingga ia bisa menentukan jalan hidupnya sendiri. Sehingga dari itu, Abu Hanifah menyimpulkan ijtihad hukum bahwa perempuan muslimahmemiliki hak untuk menikahkan dirinya sendiri, meskipun walinya tidak setuju atau tidak mengetahuinya.

\section{Kesimpulan}

Abu Hanifah termasuk ulama yang sangat banyak sekali pengikutnya, bahkan madzhab hanafi adalah madzhab yang paling banyak di ikuti oleh kaum muslimin seantero dunia, seperti Mesir, Syam, Negara Romawi, Iraq, Hindia, Cina.

Madzhab Hanafi terkenal dengan sebutan "Ahli Ro'y” (ahli logika, dan sering menggunakan logika dalam menyimpulkan hukum), sebab memang pada saat itu hadits cukup jarang di Iraq, sehingga membuat mereka sering menggunakan Qiyas. Kondisi sosio politik pada masa Abu Hanifah cukup mewarnai corak fikir beliau, yang berimplikasi pada metodologi penyimpulan hukum dalam madzhabnya.

Realitas sosial yang terlihat di masyarakat, sering ditemukan kasus terkait perkawinan yang tidak sesuai dengan Kompilasi Hukum Islam. Kenyataannya seseorang yang akan menjalani pernikahan tidak seluruh prosesnya berjalan secara lancar, khususnyatatkala seorang laki-laki mau menikahi seorang perempuan yangternyata tidak disetujui oleh orang tuanya yang sebenarnya bertindak sebagai walinya. Dampak yang muncul dari hal tersebut adalahbanyak ditemukan kasus pernikahan yang cukup problematik di masyarakat, misalnya kawin paksa, kawin lari, seks pra nikah dan lain sebagainya.

Pemikiran ijtihad fiqih Abu Hanifah terkait bolehnya Wanita melakukan pernikahan tanpa adanya wali tentuakan tetap kantradiktif dengan aturan yang ada dalam Kompilasi Hukum Islam. Jika pun kita diusahakan untuk mencari celah titik temu diantara dua pendapat yang kontradiktif mengenai wajib tidaknya wali dalam pernikahan, bisa jadiditemukan kesimpulan bahwa konsep "nikah tanpa wali" dapat menjadi solusi bagi beberapa kasus yang menyimpang dari ketentuan pasal-pasal KHI. Tentunya, hal ini hanya diaplikasikan secara khusus pada kasus-kasus tertentu dan dengan syarat tertentu pula.

\section{Daftar Pustaka}

Addzahabi Muhammad bin Ahmad bin Utsman. (n.d.). Manâqib al-Imâm Ab̂̂̀ Hanîfah. Lajnah Thya Al-Ma'arif Al-Nu'maniyyah.

Al-Baklabakki, M. (1992). Mu'jam A'lam Al-Maurid. Dar Al-Ilmi Li Al-Malayin. Bakr, A.-K. A.-B. A. bin A. A. (n.d.). Târîkhu Baghdâd. Dar Al-Kutub al-Ilmiyah. 
Fakhrudin Al-Rozi. (n.d.). Mafâtih al-Ghoib. Dar Ihya al-Turots al-Arobi. Ghawji, W. S. (1993). Abu Hanifah Imamu Al-Aimmah Al-Fuqaha. Dar Al-Qalam. Hasan, M. A. (2000). perbandingan mazhab figh. PT. Raja Grafindo Persada. Ibn Rusyd. (1995). Bidayatul Mujtahid wa Nihayatul Muqtashid. Dar Al-Fikr.

Ramulyo, M. I. (1996). Hukum Perkawinan Islam. Bumi Aksara.

Tulab, T. (2017). Tinjauan Status Wali dalam Perkawinan Berdasar Pendekatan Feminis. Ulul Albab: Jurnal Studi Dan Penelitian Hukum Islam, 1(1), 152. https://doi.org/10.30659/jua.v1i1.2223

Wahbah Az-Zuhaili. (2009). al-Fighu al-Islamy wa Adillatuhu. Dar Al-Fikr.

Zuhroh, M. A. (1948). Abu Hanifah hayatuhu wa ashruhu_ârôuhu wa fiqhuhu. Dar alFikr al Arabi. 